\title{
Review
}

\section{帯電に着目した電子写真用現像剤の材料 および現像器構成の研究}

\section{Study on Electrophotographic Two-Component Developer and the Developing Device from Aspect of Toner Charge}

\author{
伊藤 昇 \\ Noboru Ito
}

\begin{abstract}
In electrophotography consisting of charged toner transfer processes, the toner charge is of great importance. Toner charge of two component developer is determined by work function, toner content, charging sites density etc. These parameters are dependent on not only the toner materials and their composition but also the manufacturing condition. Charging property of each material is estimated by their chemical properties, i. e., whether they are the electron donor or the acceptor. Toner charge stability during printing is influenced by the properties of developer and mixing process as well as the stress exerting on toner in a developing device. By employing an easy simulation method, it is possible to estimate the best constitution of the device and developer in various printing speed ranges without conducting experiments.
\end{abstract}

Keywords : Electrophotograpy, Developer, Toner charge, Developing device, Mixing

\section{1.はじめに}

1937 年 Carlson が発明した電子写真プロセスは, 今や MFP (Multi-Function Peripheral, 多機能複 写機）やプリンタの中核を担っており，成熟技術と言 われながらも，今なお各企業が競って技術の研究開発 にしのぎを削っている。それは，MFPゃプリンタに 替わるデバイスの商品化がまだ難しい現在, 10 兆円 とも言われる市場は, 成長はあっても縮小する気配が

2005年 11 月 4 日受付

コニカミノルタビジネステクノロジーズ（株）機器開発本部画像技 術開発部

( ( $442-8585$ 愛知県豊川市八幡町東赤土 2 番地)

TEL 0533-88-8156

Image Engineering Development Division, Konica Minolta Business Technologies Inc.

(2 Higashi-akatsuchi, Yawata, Toyokawa, Aichi 442-8585, Japan)

<著者紹介>

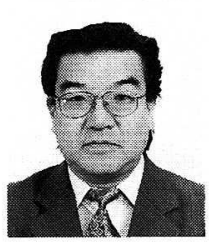

1978年信州大学大学院工学研究科合成化学専 攻修了。ミノルタカメラ (株) 研究部に配 属, 1992年より開発部に異動, 現在, コニ力 ミノルタビジネステクノロジーズ (株) 機器 開発本部画像技術開発部所属。

専門 : 電子写真用現像剂材料, 電子写真用作 像プロセス, 現像剂挙動解析。

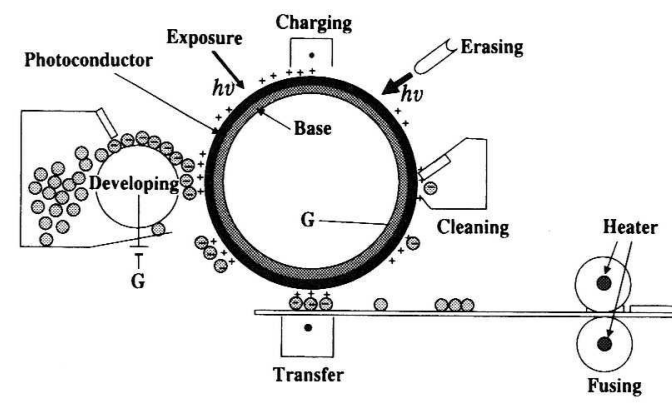

Fig. 1 Schematic diagram of electrophotographic process

なく，ビジネスとして重要だからである。しかし，そ の基本技術は今も変わっていない点で, 特異である。

Fig. 1 は, 現在一般的に使われている電子写真プロセ スの概略であるが，主要部分はCarlsonの手書きの 図と何も変わっていない。光半導体を帯電し, アナロ グ機のような正現像プロセスの場合は非画像部を，デ ジタル MFP やプリンタのような反転現像プロセスで は画像部を露光して, 導電性にし, 電荷をキャンセル して潜像を作成する。そこへ，帯電したトナーをクー ロン力で付着させ顕像化させる(すなわち現像)。こ のトナー像を逆電荷で転写部材（メディアそのもので 
あったり，転写ベルトであったりする）に転写させ， 最後にトナーを熱溶融し定着させる。

ここで, 最重要パラメータの一つが, 粉体であるト ナーの帯電である。ハードメーカーもトナ一供給メー カーも, 電子写真プロセスの開発開始以来長年にわた り，この古くて今なお理論的なアプローチが難しい “粉体と帯電”の両者に取り組んできた。

2 成分現像剂におけるトナ一带電は, トナ一材料・ 製造条件とキャリア材料という現像剂自体と，現像剂 を使いこなす現像器の混合システムと負荷とに依存す る。本稿では, この両方について解説する。

\section{2. 電子写真現像剂の帯電理論}

2 成分現像剂の帯電理論は, 数多く提案されてい る。多くは, Anderson ${ }^{1)}, \mathrm{Shein}^{2)}, \mathrm{Nash}^{3)}$, 岸本 ${ }^{4)}$ らが提唱する, 仕事関数差・荷電点数・混合比をパラ メータにしたモデルである。詳細は文献に譲るが, い ずれのモデルも, 帯電量が, 仕事関数差打よび荷電点 数やこの数が依存するトナー・キャリア表面積と比例 し, 混合比に反比例する形となっている。他には, 近 藤や栗田 ${ }^{5)}$ が提唱しているトナ一-キャリア間の帯電 による電界 $E_{\mathrm{k}}$ を基にしたモデルである。本モデルに より導出される式も, 荷電点数やトナー・キャリア表 面積に比例し，トナ一混合比に反比例している。いず れのモデルも, 実験的に経験する“帯電量と混合比と の反比例関係”を説明しうる。

以上のモデルは, 初期的な带電モデルである。耐刷 （プリントの繰り返し）による帯電量変動の研究は, あまり見られない。実際の MFPやプリンタでは, 初 期特性以上に重要なことは, 耐刷による帯電安定性で ある。プリント動作では, 環境変動 (温度, 湿度)・消 費トナー量 (印字面積) ・連続プリント枚数・駆動時 間等, 現像剂帯電量に大きく影響する様々な摚乱因子 がある。また，トナーを帯電させる現像器の構成に も，大きく影響される。これら多くの因子を考虑しな がら, 現像剂材料や製造条件の研究・現像器構成研究 をしなければならない。

\section{3. トナー材料と帯電性}

\section{1 トナー構成および種類}

トナーは, 主樹脂・着色剂・WAX（定着プロセス の離型性付与) ・荷電制御剂 (= CCA) からなる母粒子 に, コロイダルシリカ・酸化チタン・チタン酸化合物 (例えば $\mathrm{SrTiO}_{3}$ ) ・樹脂微粒子などが表面に処理されて いる。この処理剂は, $1 \sim 2 \mu \mathrm{m}$ のチタン酸化合物以

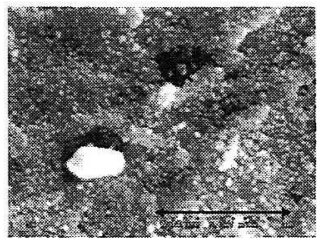

Toner A

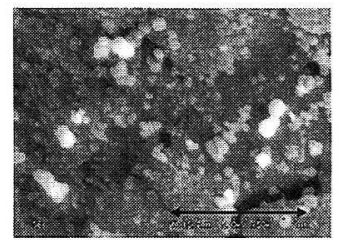

Toner B
Fig. 2 SEM photography of toner surface $\longleftrightarrow$ Scale : $1 \mu \mathrm{m}$

外は, $30 \mathrm{~nm} \sim 100 \mathrm{~nm}$ くらいの微粒子である。Fig. 2 は, トナーの表面状態であるが, 様々な粒子が処理さ れている。

トナーの製法は, 混合・混練・粉砕・分級・後処理 工程からなる，いわゆる粉砕法が主流であったが，近 年, 樹脂合成時にトナー組成物を導入して, 重合と同

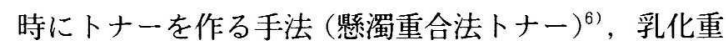
合微粒子をトナ一組成物と混合し熱で会合させる手法 (乳化会合法トナー $)^{7.8)}$, 樹脂とトナ一組成物を有機 溶媒に溶解後, 水系溶媒中で粒子を作製し, 熱で有機 溶媒を揮発させる手法 (溶液懸濁法トナー) ${ }^{9}$. 10) など, ケミカル法が搪大しつつある。Fig. 3 に，各トナーの SEM 写真を示す。このケミカル法が拡大している理 由は, 形状制御, カプセル化による機能分離を適用し た低融点化（高融点のシェルに低融点のWAX や樹 脂を内包させ，耐熱性と低温定着を両立させる), 小 径化や粒径分布のシャープ化など, 粉砕法では困難な 高機能付与が可能なことである。これらの機能は, 高 画質化 (性能)・トナー低消費量化（コスト）や定着低 エネルギー化（エコロジー）につながる。

さて, トナ一の帯電は, 理論的には構成される材料 の仕事関数がパラメータとなるはずであるが, 上述の ように様々な成分から構成され，かつ，その存在状態 が多様であり (内在, 外在, 表面露出の有無など), また，その状態か製造条件とも密接につながっている ため, 各材料の仕事関数からトナー帯電量を予測する

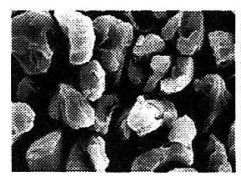

(a)

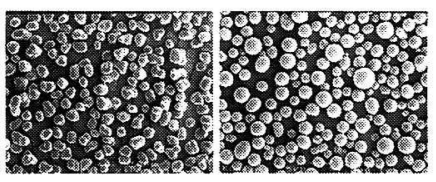

(b) (c)
Fig. 3 SEM photography of toner :

(a) Pulverized toner

(b) Emersion Aggregation toner

(c) Suspension polymerzation toner $\longleftrightarrow$ Scale : $10 \mu \mathrm{m}$ 
のは，極めて困難である。それよりは，材料設計は， まず電子の受容・供与により支配される化学的性質を 基に大まかに行い, その後, 製造条件・詳細な組成比 を微調整し, 帯電性評価はトナー帯電量の直接測定を 採用するほうが, 開発速度の観点ではメリットがあ る。そして，これらのデータベースを基に，仕事関数 という基本に戻って帯電メカニズムを明らかにし, 理 論体系を構築して, より自由にパラメータ制御できる ようにするのが得策である。

\section{2 材料の化学的性質之帯電性}

先に述へたように, 帯電は, 材料の電子供与性・受 容性に密接に関係している。下に, 樹脂の官能基の帯 電系列を示す。

$$
\text { 正荷電性ヶ } \begin{aligned}
\qquad & \mathrm{NH}_{2}>-\mathrm{OCH}_{2} \mathrm{C}_{6} \mathrm{H}_{5} \\
& >-\mathrm{OC}_{2} \mathrm{H}_{5}>-\mathrm{OCOCH}_{3} \\
& >\mathrm{COOCH} \mathrm{H}_{3}>-\mathrm{OH}>\mathrm{COOH} \\
& >-\mathrm{Cl}>-\mathrm{NO}_{2}>-\mathrm{F} \Rightarrow \text { 負荷電性 }
\end{aligned}
$$

電子を引き寄せる傾向のあるフッ素を含む樹脂は, 強い負帯電性を示し，逆に不対電子を持ちプロトンを 取り込みやすい，言い換えれば，電子を放出しやすい アミノ基は強い正帯電性を示す。実際, ニグロシン系 染料や 4 級アンモ二ウム塩は, 正荷電性 CCA として 広く使われている。また, アミノアクリル樹脂は正荷 電性トナー用樹脂である。アミノアクリル樹脂，スチ レンアクリル樹脂, ポリエステル樹脂, テフロンをト ナー粒径 $(14 \mu \mathrm{m})$ に粉砕し, キャリアと混合して帯 電量を測定すると, 最も正帯電を示すのがアミノアク リル樹脂粒子, 最も負帯電となるのがテフロン粒子, ポリエステル粒子は適度な負帯電, スチレンアクリル 樹脂粒子は弱負帯電である。これらの樹脂を使ったキ ヤリアによるトナー帯電性樹脂の荷電性 ${ }^{11}$ が, その ままトナーの帯電量や極性（キャリア荷電性とは逆） を反映している。

CCA では, 付加させる官能基のハメット置換基定 数と, CCA 単体の帯電性を研究した例がある ${ }^{12)}$ 。

ハメットの置換基定数は, 次のように定義される。

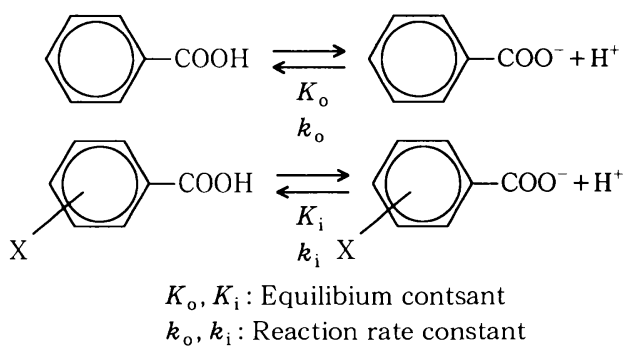

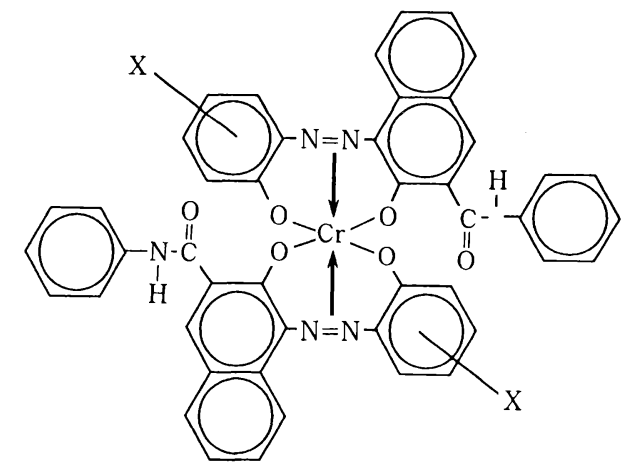

Fig. 4 Structure of $\mathrm{Azo}^{-}$Chromic complex CCA

安息香酸の解離定数 $K_{0}$ および反応速度定数 $k_{0}$ と, 任意の置換基が付加した安息香酸化合物の解離定 数 $K_{\mathrm{i}}$ および反応速度定数 $k_{\mathrm{i}}$ との間に下記の関係が成 り立つ。

$$
\log \left(k_{\mathrm{i}} / k_{\mathrm{o}}\right)=\sigma \log \left(K_{\mathrm{i}} / K_{\mathrm{o}}\right)=\sigma \rho
$$

この $\log \left(K_{\mathrm{i}} / K_{\mathrm{o}}\right)=\rho$ をハメット置換基定数と称す る。置換基定数は, 置換基の電子吸引性を示すもので あり, 電子吸引性が強いほど誘起効果で負イオンが安 定化し， $\rho$ が大きくなる。アゾ系含金属染料（Fig. 4) に各種官能基を付加させ, 置換基定数と帯電レベルと の関係を示したのが，Fig. 5 である。付加官能基の $\rho$ が大きくなる，つまり電子吸引性が大きくなるに従 い, ほぼ直線的に負帯電レベルが大きくなるのが分か る。

CCA は, 帯電レベルの確保だけでなく，トナー帯 電立ち上がり（飽和帯電量に達するまでの時間）を良 くする目的で添加される ${ }^{13)}$ 。CCA が存在しない場合 は，単にトナー樹脂表層とキャリア樹脂表層間の接触 により授受されるわずかな電荷で帯電が進むため, 帯 電は接触確率依存となる。一方, CCA は, 多くの電 荷を供給して一度の接触でかなりの帯電をさせる,

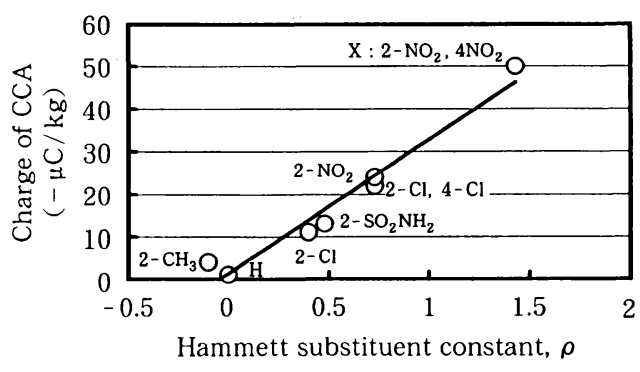

Fig. 5 Dependence of Hamett substituent constant of pending group on charge of Azo-Chromic complex CCA 


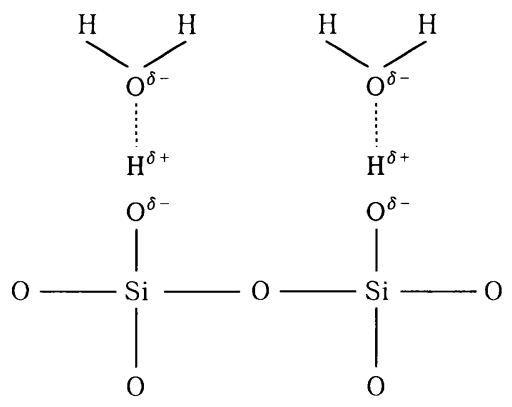

Fig. 6 Surface structure of silica

$\mathrm{CCA}$ の体積固有抵抗が低い，などの理由で帯電速度 が速くなると考えられる。

最近のトナーでは，環境およびコストの側面から $\mathrm{CCA}$ を使わないことがある。この場合, 樹脂ととも に, 後処理剂の荷電性が重要となる。広く使われてい るコロイダルシリカは，負荷電性を示し，そのまま 使えば負荷電性トナーとなるが，その表面はFig. 6 に 示すように, $-\mathrm{OH}^{-}$や $-\mathrm{H}^{+}$か解離しており，水分子 の化学吸着や物理吸着が起こるため, 荷電を著しく 阻害する。そのため，カップリング剂で疎水化処理を 施す。Fig. 7 に，シランカップリング剂の例を示す。 この踈水化剂の種類によって, 正にも負にも帯電す る。上述のように，フッ素系の材料を使うと負に荷電 し，アミノ基を有する材料を処理すると正に荷電す る。

導電性の酸化チタンは, 最近多用されているが, 特 許などから推測すると過帯電防止が目的と思われる。

キャリアの荷電性付与でも同様のことが成り立つ。 古くは，正帯電性トナー用キャリアのコート剂とし て, テフロンが知られている。昨今のデジタル化で, トナーは負荷電性が圧倒的に多いので，キャリアは正 荷電性が求められる。Fig. 8 は, コート剂の一例であ

\section{Amino-coupling agent}

$\mathrm{NH}_{2} \mathrm{CH}_{2} \mathrm{CH}_{2} \mathrm{NHCH}_{2} \mathrm{CH}_{2} \mathrm{CH}_{2} \mathrm{Si}\left(\mathrm{OCH}_{3}\right)_{3}$

\section{Vinyl-coupling agent}<smiles>C=C(C)C(=O)OCCCOC</smiles>

Epoxy - coupling agent

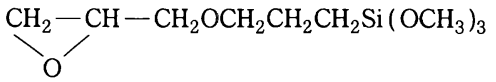

\section{Haloid coupling agent}

$\mathrm{ClCH}_{2} \mathrm{CH}_{2} \mathrm{CH}_{2} \mathrm{Si}\left(\mathrm{OCH}_{3}\right)_{3}$

Fig. 7 Silan coupling agent

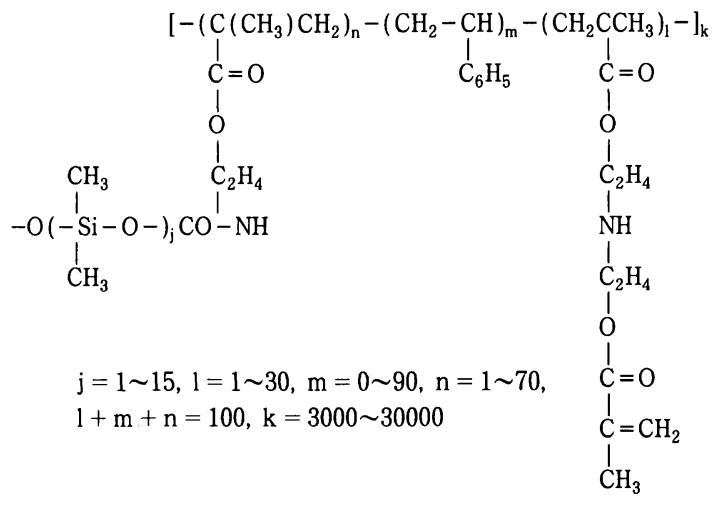

Fig. 8 Silicon resin for carrier coating るが，アミノ基を含有する材料が多い。ただし，アミ ノ基は，水分を吸着して表面抵抗低下を起こすため, 帯電量低下につながるので, 注意が必要である。

\section{3 製造条件とトナ一帯電}

トナー製造条件は，帯電に対して組成と同じくらい 重要である。トナーの帯電性は, 組成半分, 製造条件 半分といったところである。

製造条件において帯電に関係する主因子は，材料分 散性であり，材料混合工程と混練工程が重要である。

Fig. 9 は, トナー帯電立ち上がり性と, 表面に露出 する CCA 量との関係を示したものである。縦軸は混 合時間が 3 分と 81 分での帯電量比で，小さいほど帯 電立ち上がりが早い。表面の露出 CCA は, 分散性が 覀いほど大きくなるので，観測される CCA 量が多く なる。分散性が悪いほど, 帯電立ち上がり速度が悪く なる。これは，CCAとキャリアとの接触確率が小さ くなるためと考えられる。混練工程では, 混練物への シェアリングが大きく関係し，大きいほうが顔料にか

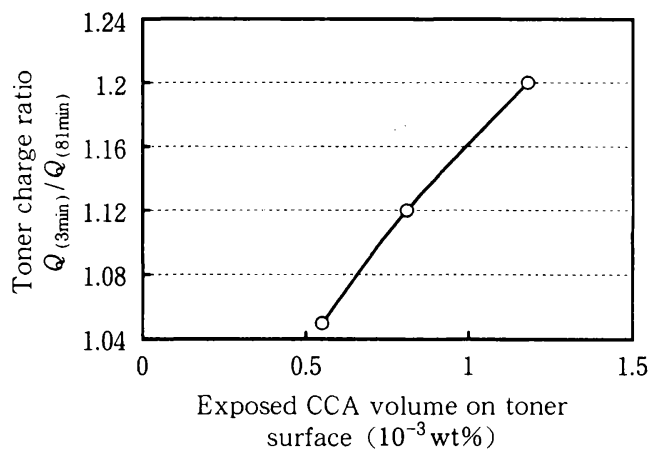

Fig. 9 Dependence of CCA volume on toner surface on charging rate of toner $Q_{(3 \min )}, Q_{(81 \min )}$ : Toner charge of mixing for $3 \mathrm{~min}$ and for $81 \mathrm{~min}$, respectively 


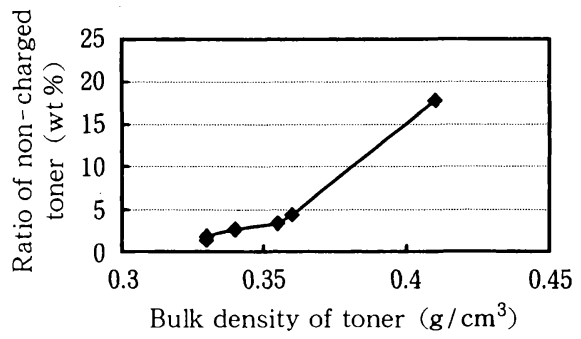

Fig. 10 Influence of flowing property to noncharged toner ratio in Add-Mixing

かる力が大きくなる。その一つの因子は, 温度であ る。なるへく低温で高粘度のほうが，シェアリングが 大きくなり，分散性がよくなる。もう一つは，混練部 材回転数である。回転数を大きくすると, 帯電性能が 低下する傾向 ${ }^{13)}$ がある。回転速度が大きくなること で動的粘弾性と印加力との適正な関係が崩れ，混練物 へのシェアリング伝達が悪くなるためと考えられてい る。

\section{4. 実機での帯電挙動に対するトナー設計}

実機でのトナ一帯電挙動推定は，無垢のキャリアと トナーとの荷電性能だけでは，不十分である。実機て は，トナー消費によりトナー混合比が低下すると，磁 気センサーや光学センサーが検知してトナー補給命令 を出す仕組みになっているが，その時のキャリアの状 態はほぼ 8〜9割の被覆率でトナーがキャリアを覆っ ている状態であり，トナーが接触可能なキャリア表面 は限られている。したがって，単純にキャリアとト ナーを混合するのではなく，あるトナー混合比の現像 剤に更にトナーを混合したときの帯電挙動が重要であ る。これを Add-Mixing という。Fig. 10 は，トナー の流動性能（かさ密度）とAdd-Mixing による帯電 性能評価結果である。帯電性能は，無電界で現像ロー ラを回転したときに飛散する帯電不良トナ一量比率で 表した。トナー流動性と Add-Mixing 性能が依存し ている。Fig. 11 は，同様に Add-Mixing 法で作製し た現像剤の実機評価結果である。縦軸は非電界部，す なわち白紙部でのトナーカブリ度合いをあらわしてお り，数值が大きいほどカブリが悪い。横軸はトナーの かさ密度である。実機の画像データと Add-Mixing 法によるデー夕は，一致している。一般に流動性の悪 いトナーは，性能が悪いように思われがちであるが, キャリアとうまく接触するためには，適度な流動性に 抑えて摩擦力でキャリアがトナーを捕捉する必要があ ることを示している。

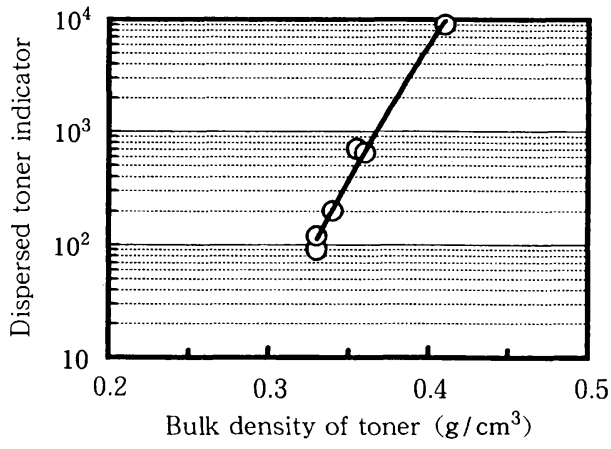

Fig. 11 Influence of flowing property to image quality

\section{5. 帯電から見た電子写真用現像器の設計}

\section{1 初期的な特性と現像器構成}

2 成分現像器を帯電から考えると，トナーと現像剂 との混合システムが重要である。電子写真機器が上市 されて以来，様々な構成が提案されてきたが，この数 年は小型化の市場要求から，高速プロダクション領域 を除けば，複数本（多くは 2 本）のスパイラルからな る極めてシンプルな構成が主流になっている。

粉体混合の様子を Fig. 12 に示す。縦軸は，混合比 ばらつきを標準偏差で表したもので，横軸は混合時間 である。このように，混合は移動 $\Rightarrow$ 分割 $\Rightarrow$ 拡散という プロセスを経て進む。現像器の混合部設計は，ほとん どが分割をいかに効率よく行うかに注力している。拡 散は, トナーとキャリアの特性でほぼ決まるからであ る。キャリアとトナーの帯電性がよければ，自然と拡 散が進む。

さて，粉体混合現象を表す式は，古くから粉体の種 類に応じて幾つか提案されている ${ }^{14)}$ 。Fick の拡散方 程式から導出される式を除けば，ほとんど簡単な微分 方程式から導かれる。その中でも最もシンプルな Eq （2）を使う。あえて複雑な式を使う必要がないからて

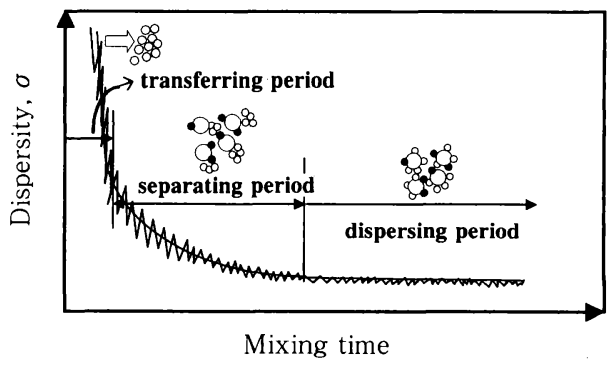

Fig. 12 Mixing process of powder 


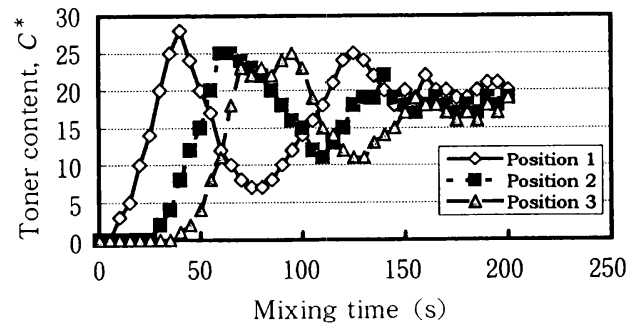

Fig. 13 Change of toner content on some position by mixing

ある。

$$
\sigma_{\mathrm{t}}=\sigma_{\mathrm{o}} \exp (-k t)
$$

$t:$ 混合時間, $\sigma_{\mathrm{o}}$ : 初期混合比ばらつき,

$\sigma_{\mathrm{t}}: t$ での混合ばらつき, $k:$ 混合速度定数

現像器の混合実験では，まず，キャリアを現像器に 分散後, トナー供給部に所定量の異色トナーを投入 し, 現像器駆動時間に応じて各部の色彩を測定し, 混 合比に換算し、ばらつきを算出する ${ }^{15)}$ 。Fig. 13 は， そ の測定結果の一例である。縦軸は混合比と比例関係に ある現像剤の彩度 C*である。

Fig. 14 に, 実験に供した現像器構成を示す。シン プルなスパイラル， スパイラルの羽根の一部を切り欠 いて現像剤搬送に速度差を持たせて分割を促進する構 成，スパイラルを隔てる壁の一部を除いて一部が横流 れする構成の 3 種類である。

Fig. 15 は，混合比ばらつき（標準偏差で表現）の 対数 $\ln \left(\sigma_{t}\right)$ を，混合時間 $t$ に対してプロットしたも のである。傾斜が混合速度定数 $k$ となる。Type I に 比較すると, Type III は混合が早く進んでいるのが

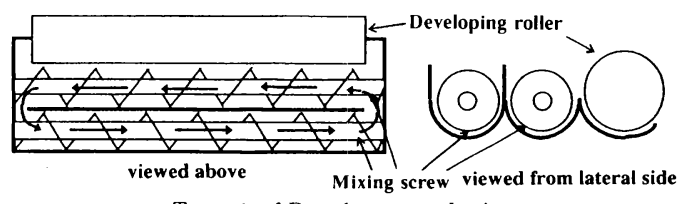

Type I of Development device
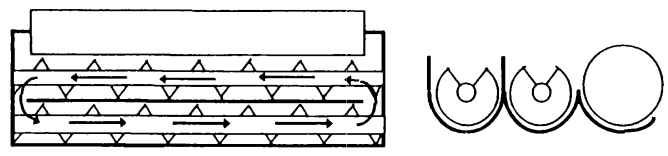

Type II of Development device
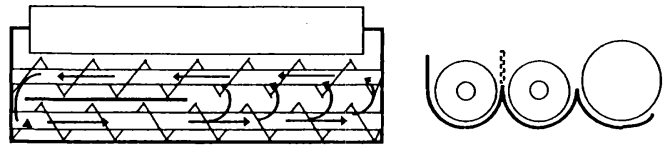

Type III of Development device

Fig. 14 Structures of developing devices
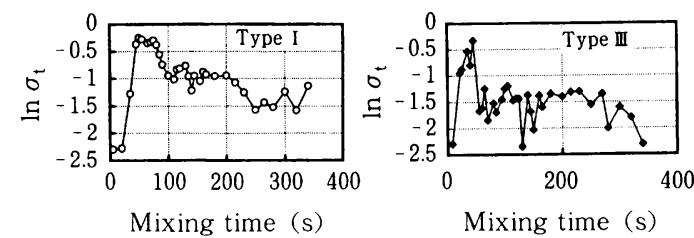

Fig. 15 Mixing property in Type I and III

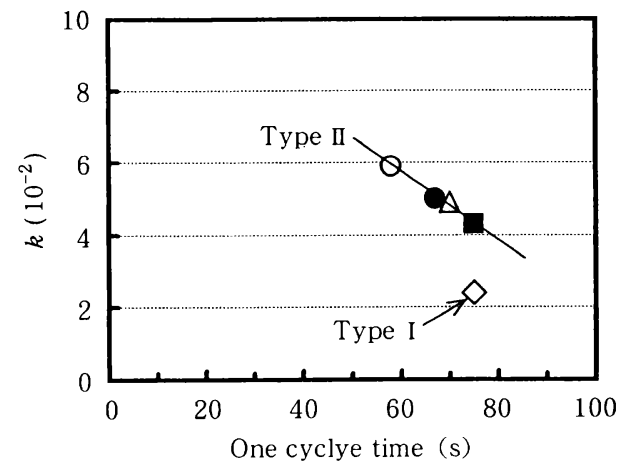

Fig. 16 Mixing rate constance in Type I and II

分かる。Fig.16は, Type I と Type II ついて, 駆 動速度を変えた時の $k$ をプロットしたものである。 駆動速度が速くなると，当然ながら $k$ は大きくなる が, 構成のタイプが同じであれば一つのラインに乗 る。

Type I と Type III の帯電性能を検討したのが, Fig. 17 である。混合実験と同様の方法で, 現像器駆 動時間に応じて各部の帯電量と混合比を測定した。混 合比が変わると当然帯電量は変化するので, 帯電性能 を栗田のトナーーキャリア間接触電界強度 $E_{\mathrm{k}}$ で表現 した ${ }^{5)}$ 。この值が大きいほど帯電性能がよい。混合性 能の良好な Type IIIの方が带電性も良好なことが分か

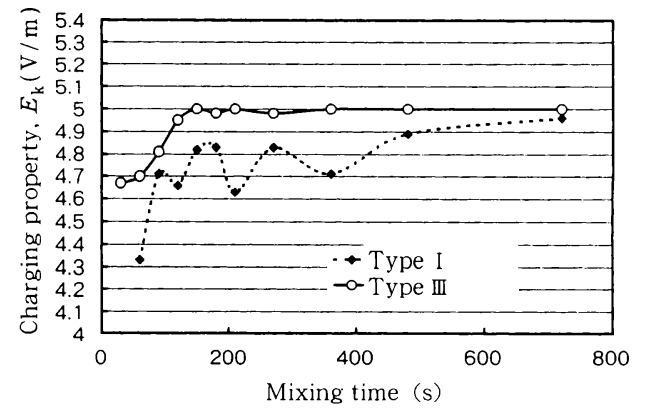

Fig. 17 Change of charging property, $E_{\mathrm{k}}$, as mixing time $\left(E_{\mathrm{k}}\right.$ meaning field between toners and carrier) 


\begin{tabular}{|l|c|c|c|c|c|c|c|c|c|c|c|c|}
\hline $\mathrm{S} 1$ & $\downarrow$ & $\downarrow$ & $\downarrow$ & $\downarrow$ & $\downarrow$ & $\downarrow$ & $\downarrow$ & $\downarrow$ & $\downarrow$ & $\downarrow$ & $\downarrow$ & $\downarrow$ \\
\hline $\mathrm{R}$ & 1 & 2 & 3 & $\bullet$ & $\cdot$ & $\cdot$ & $\mathrm{k}-4$ & $\mathrm{k}-3$ & $\mathrm{k}-2$ & $\mathrm{k}-1$ & $\mathrm{k}$ & $\bullet$ \\
\hline & $\rightarrow$ & $\rightarrow$ & $\rightarrow$ & $\rightarrow$ & $\rightarrow$ & $\rightarrow$ & $\rightarrow$ & $\rightarrow$ & $\rightarrow$ & $\rightarrow$ & $\rightarrow$ & $\rightarrow$ \\
\hline & $\uparrow$ & $\downarrow$ & $\downarrow$ & $\downarrow$ & $\downarrow$ & $\downarrow$ & $\downarrow$ & $\downarrow$ & $\downarrow$ & $\downarrow$ & $\downarrow$ & $\downarrow$ \\
\hline & $\uparrow$ & 0 & 0 & 0 & 0 & 0 & 0 & 0 & 0 & 0 & 0 & $\downarrow$ \\
\hline & $\leftarrow$ & $\leftarrow$ & $\leftarrow$ & $\leftarrow$ & $\leftarrow$ & $\leftarrow$ & $\leftarrow$ & $\leftarrow$ & $\leftarrow$ & $\leftarrow$ & $\leftarrow$ & $\leftarrow$ \\
\hline $\mathrm{F}$ & $\bullet$ & $\cdot$ & $\bullet$ & $\mathrm{n}+1$ & $\mathrm{n}$ & $\mathrm{n}-1$ & $\mathrm{n}-2$ & $\mathrm{n}-3$ & $\mathrm{n}-4$ & $\bullet$ & $\bullet$ & $\bullet$ \\
\hline $\mathrm{S} 1$ & $\downarrow$ & $\downarrow$ & $\downarrow$ & $\downarrow$ & $\downarrow$ & $\downarrow$ & $\downarrow$ & $\downarrow$ & $\downarrow$ & $\downarrow$ & $\downarrow$ & $\downarrow$ \\
\hline
\end{tabular}

\begin{tabular}{|c|c|}
\hline S1 & eve (developing roller) \\
\hline$\rightarrow$ & rection of developer stream \\
\hline , b, c, d, e & $\begin{array}{l}\text { gree of dispersal from cell } n \text { to cell } n-1, n-2, \ldots n-5 \text {, resp } \\
\text { ighbour cell of upper stream from cell } n\end{array}$ \\
\hline Volume of carrier & $\begin{aligned} R C_{\mathrm{n}}(t)= & \mathrm{a} \times R C_{\mathrm{n}}(t-1)+\mathrm{b} \times R C_{\mathrm{n}-1}(t-0) \\
& +\mathrm{c} \times R C_{\mathrm{n}-2}(t-1)+\mathrm{d} \times R C_{\mathrm{n}-3}(t-1)+\mathrm{e} \times R C_{\mathrm{n}-4}(t-1)\end{aligned}$ \\
\hline Volume of toner & $\begin{aligned} R T_{\mathrm{n}}(t)= & \mathrm{a} \times R T_{\mathrm{n}}(t-1)+\mathrm{b} \times R T_{\mathrm{n}-1}(t-1) \\
& +\mathrm{c} \times R T_{\mathrm{n}-2}(t-1)+\mathrm{d} \times R T_{\mathrm{n}-3}(t-1)+\mathrm{e} \times R T_{\mathrm{n}-4}(t-1)\end{aligned}$ \\
\hline ontetnt & $R T C_{\mathrm{n}}(t)=R T_{\mathrm{n}}(t) /\left(R T_{\mathrm{n}}(t)+R C_{\mathrm{n}}(t)\right) \times 100(\%)$ \\
\hline
\end{tabular}

Fig. 18 Simulation of developer mixing

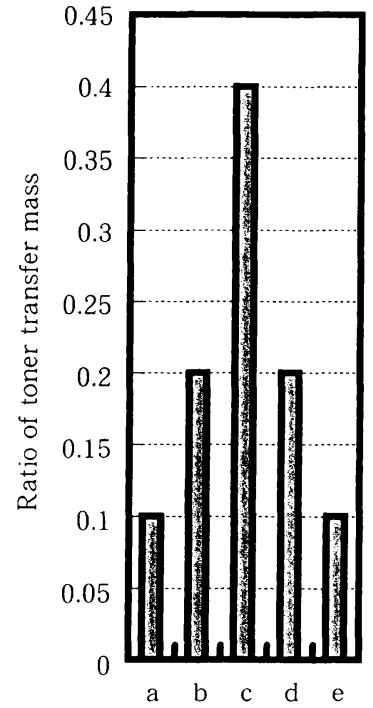

Fig. 19 Degree of toner dispersal

る。すなわち，いかに混合性能を上げるかが带電性能 を左右すると言える。

この挙動は, 簡単なシミュレーションが可能であ る。

まず，Fig. 18 に示すように，現像器を適当な大き さのセルに分割する。各セルには一定量のキャリアが 存在する。このセルの最上流に所望の混合比となるよ うにトナーを存在させる。駆動之同時に，一定時間に セル間を移動する現像剂量を決め（実験から求めても よい）る。下流側各セルへのトナー移動は，Fig. 19

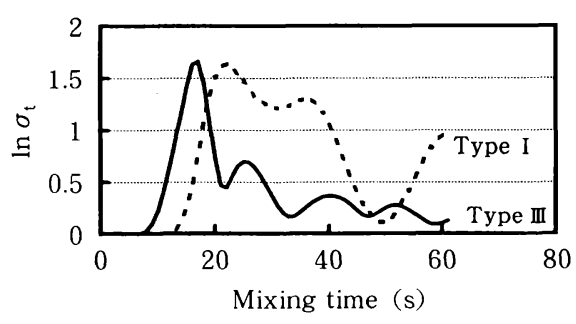

Fig. 20 Change of $\sigma_{\mathrm{t}}$ to mixing time

のような分布を持つものとする。綐軸は, トナー移動 量割合である。一定駆動時間ごとにおける各セルでの トナー混合比を逐次計算して, トナー混合挙動を求め る。Type I の現像器のように単純に移動する場合 と, Type IIIのように一部隔壁を無くして横流れする 場合の計算結果を Fig. 20 に示す。ほぼ実験結果を再 現している。

マシン速度に応じて, 各セルの移動量, 移動方向, トナー移動を様々に変えて最適条件を求めれば，その 条件を達成するための構成を推定することができる。

\section{2 プリントに伴う帯電性能変化}

初期的な帯電性に加え, プリントに伴う帯電安定性 が重要なことは先に述へた。通常, プリントに伴い 帯電量は小さくなるが, これは, トナー成分, 特に CCA がキャリアに移行してキャリアとトナーとの仕 事関数差が小さくなることによる ${ }^{13)}$ 。

これを防ぐには，以下のように幾つかの手立てがあ る。

1) キャリアの表面エネルギーを小さくして, 異物の 


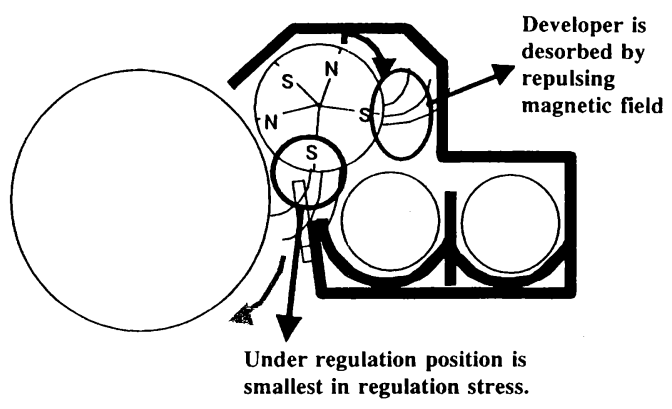

Fig. 21 Developing device for tandem system

付着を抑える

2）トナーの CCA 分散性を上げて，移行を抑制する

3) CCA が移行しても帯電量低下が起こりにくくす る

4 ) 現像器中での現像剂への機械的ストレスを小さく して, トナーとキャリアの過剰な接触負荷を抑え る。

1）〜 3) は現像剂の組成・製造条件からのアプ ローチである。例えば，1）の場合だと, シリコン樹 脂やフッ素樹脂を，キャリアのコート剂として使用す る。昨今のデジタル機用現像剂は, 負帯電性トナーが 圧倒的に多いので, 負帯電性のフッ素樹脂ではなくシ リコン樹脂を使う例が多い。2）は前項で述べた通り である。3）はキャリア構成を変えることにより可能 となるがこれは本誌の別の論文に詳細が述べられて いる。4）の現像器からのアプローチでは, 現像剂摫 拌や規制によるストレスをいかに小さくするかに腐心 している。先に述べたように，混合部は単純なスパイ ラルのペアからなっている例が圧倒的に多いが, この
構成は負荷軽減の点でも優れている。規制部でのスト レス低減は，まず規制位置である。Fig. 21 は，A 社 タンデム型システムに使われている現像器である。下 位置に規制部が設けられている。下位置にあること で，規制部への過剰な現像剂溜りが抑えられ，ストレ スが低減される。ローラの回転トルクで示すと, 上位 置に比べ半分くらいになる。また, 現像プロセスで は, 現像ローラから現像後の現像剂を脱離させる必要 があるが, 本システムでは反発磁界と重力により自然 脱離するように設計されている。

規制部での磁気的力を受けにくくするには，キャリ アの磁化低減も効果がある。本現像システムに使われ ているキャリアは, 通常のフェライトコートキャリア ではなく，樹脂中に磁性粉を分散したコアに樹脂コー トされた構造となっている。コアは, 眯濁重合トナー と同じように，磁性粉をモノマーに分散して重合して 作製する。樹脂が含まれることで，その磁化は，通常 のフェライトに比へ $2 / 3$ 半分程度のため, 規制部で の現像剂磁気凝集が抑えられ，ストレスが緩和され る。このような工夫が, キャリアの長寿命化につなが る。

\section{6. 最後に}

電子写真用現像剂の帯電設計は, 理論が実際の材料 へのフィードバックが進まないままに, 各社で材料研 究や評価法開発が進められ，経験則や膨大なデータ ベースが出来上がっている。今後は,これらを整理し て, 理論的な解析を進めることで, より汎用的な粉体 帯電理論構築につながると考える。

\section{Nomenclature}

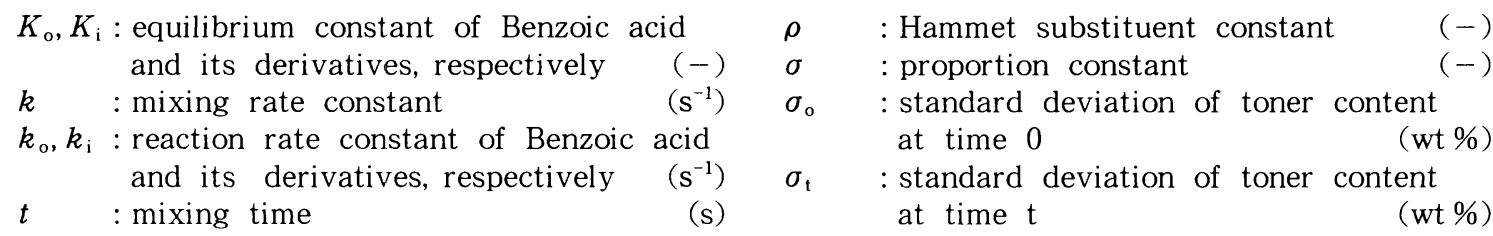

\section{References}

1) Anderson, J.H. et al. : "A Comparison of Experimental Data and Model Prediction for Tribocharging of TwoComponet Electrophotographic Developer", Recent Progress in Toner Technology, pp. 189-194, Soc. Image Sci. Tech., USA (1997)

2 ) Schein, L. B. : "Theory of Toner Charging", J. Image Sci. Tech., 37, 1-4 (1994)
3 ) Nash, R. : "Toner Charge Instability", Recent Progress in Toner Technology, pp. 169-180, Soc. Image Sci. Tech., USA (1997)

4 ) Kishimoto, T. : "Charge Model Comparison for the Concentration Dependency of Toner Charge", Japan Hardcopy '95, 59-62 (1995)

5 ) Kurita, T.: "The Contact Electrostatic Field between 
Powder Particles and Plain Surfaces", Electrophotography, 27, 147-153 (1998)

6 ) Uchiyama, M. : “Canon no Kemikaru Tonâ”, Chemical Toner ni kansuru Kenkyûkai, pp. 56-60, Imag. Soc. Jpn. (2003)

7 ) Ishiyama, T. : "EA Toner", Chemical Toner ni kansuru Kenkyûkai, pp. 61-67, Imag. Soc. Jpn. (2003)

8 ) Koyama, M. : "Konica Minolta Digital Toner", Chemical Toner ni kansuru Kenkyûkai, pp. 68-77, Imag. Soc. Jpn. (2003)

9 ) Choi, E.- J. et al. : "Properties and Printer Performance of Wax-containing Polyester Toners Prepared by Chemical Milling", IS\&T's NIP 18, 270-273 (2002)

10) Minamitani, T. : "Ricoh Jûgo Tonâ no Tokuchou", Chemical Toner ni kansuru Kenkyûkai, pp. 78-85, Imag. Soc. Jpn. (2003)
11) Ito, N. : "Denshishashingenzouzai no Taiden", Preprint of autumn meeting, Soc. of Powder Technol. Japan, pp. 109-110, Makuhari (2004)

12) Anzai, T.: "Taiden Seigyozai no Sayou”, Seidenki to Imeijingu", Denshi Shashin Gakkai• Seidenki Gakkai Jointo Seminâ, pp. 35-45 (1990)

13) Ito, N. : "Taiden kara mita Denshishashinyou Gennzouzai no Sosei oyobi Gennzoukikousei no Kenkyû", Preprints of 41 th Summer Symposium, Soc. of Powder Technol., Japan, pp. 19-22, Kyoto (2005)

14) Yano, T.: "Kongou Kon-neri Gijutsu", $252+\mathrm{vi} \mathrm{Ni}$ kkan Kôgyô Shinbunsha (1980)

15) Ito, N. et al. : "Mixing Property on Development Device of Electrophotography and Relation with Construction of the Mixing Part", Proceedings of Japan Hardcopy '00 Fall Meeting, pp. 32-35 (2000) 